\title{
PENINGKATAN AKTIVITAS DAN HASIL BELAJAR FISIKA MELALUI PEMBELAJARAN KOOPERATIF JIGSAW DI SMP
}

\author{
Abdul Haris Alamsah \\ SMP Negeri 12 Surakarta \\ Haris.alamsah@yahoo.com
}

\begin{abstract}
The learning process is still dominated by the activities of the lecture so that less active learners. This will have an effect on activity and learning outcomes obtained learners in physics. To overcome the need for a suitable learning model so that students are more active and kretif in solving a problem that is by learning model Jigsaw. The purpose of research, the implementation of cooperative learning model Jigsaw can improve Physical activity and learning outcomes for students of class IX B SMP Negeri 16 Surakarta, the first half of the year 20014/2015. This research is a classroom action research conducted in two cycles, each cycle consisting of planning, action, observation and reflection. Data obtained in this research include the study of students, learners and the level of activity observed in response to the results of the process pebelajaran. Indikator success when the average daily test results have been achieved>KKM. The results of the study, by using model Jigsaw can increase the activity and learning outcomes of students of class IX B SMP N 16 Surakarta academic year 20014/2015.
\end{abstract}

Keywords: cooperative, jigsaw, activities, learning outcomes

\begin{abstract}
ABSTRAK
Proses pembelajaran masih didominasi oleh kegiatan ceramah sehingga keaktifan peserta didik kurang. Hal ini akan berpengaruh pada aktivitas dan hasil belajar yang diperoleh peserta didik pada mata pelajaran Fisika. Untuk mengatasinya perlu adanya suatu model pembelajaran yang cocok agar siswa lebih aktif dan kretif dalam memecahkan suatu masalah yaitu dengan model pembelajaran Jigsaw. Tujuan penelitian, penerapan model pembelajaran kooperatif Jigsaw dapat meningkatkan aktivitas dan hasil belajar Fisika bagi peserta didik kelas IX B SMP Negeri 16 Surakarta, semester I tahun 20014/2015. Jenis penelitian ini adalah penelitian tindakan kelas yang dilaksanakan dalam dua siklus yang masing-masing siklus terdiri atas tahap perencanaan, tindakan, observasi dan refleksi. Data yang diperoleh dalam penelitian ini meliputi hasil belajar peserta didik, observasi aktifvitas peserta didik dan hasil tanggapan terhadap proses pebelajaran.Indikator keberhasilan apabila rata-rata hasil ulangan harian telah mencapai $\geq$ KKM. Hasil penelitian, dengan
\end{abstract}


menggunakan model pembelajaran Jigsaw dapat meningkatkan aktivitas dan hasil belajar peserta didik kelas IX B SMP N 16 Surakarta tahun pelajaran 20014/2015.

Kata kunci : kooperatif, jigsaw, aktivitas, hasil belajar

\section{PENDAHULUAN}

Pada abad 21 ini, kita perlu menelaah kembali praktik-praktik pembelajaran di sekolahsekolah. Peranan yang harus dimainkan oleh dunia pendidikan dalam mempersiapkan akan didik untuk berpartisipasi secara utuh dalam kehidupan bermasyarakat di abad 21 akan sangat berbeda dengan peranan tradisional yang selama ini dipegang oleh sekolah-sekolah.

Tampaknya, perlu adanya perubahan paradigma dalam menelaah proses belajar siswa dan interaksi antara siswa dan guru. Sudah seyogyanyalah kegiatan belajar mengajar juga lebih mempertimbangkan siswa. Siswa bukanlah sebuah botol kosong yang bisa diisi dengan muatan-muatan informasi apa saja yang dianggap perlu oleh guru. Selain itu, alur proses belajar tidak harus berasal dari guru menuju siswa. Siswa bisa juga saling mengajar dengan sesama siswa yang lainnnya. Bahkan, banyak penelitian menunjukkan bahwa pengajaran oleh rekan sebaya (peer teaching) ternyata lebih efektif daripada pengajaran oleh guru. Sistem pengajaran yang memberi kesempatan kepada anak didik untuk bekerjasama dengan sesama siswa dalam tugas-tugas yang terstruktur disebut sebagai sistem "pembelajaran gotong royong” atau cooperative learning. Dalam sistem ini, guru bertindak sebagai fasilitator.

Kurikulum sekarang ini menghendaki proses pembelajaran yang memberdayakan semua peserta didik untuk menguasai kompetensi yang diharapkan dengan menerapkan berbagai strategi dan metode pembelajaran yang menyenangkan, berpusat pada peserta didik, mengembangkan kreatifitas peserta didik, bermuatan nilai, etika, estetika, efektif dan efisien bermakna, dan menyedikan pengalaman belajar yang beragam.

Untuk mencapai hal-hal tersebut diatas maka harus dirancang suatu kegiatan pembelajaran yang mampu mengembangkan dan meningkatkan kreativitas, kemandirian, kerjasama, dan kecakapan hidup peserta didik guna membentuk watak atau karakter.

Guru dituntut untuk mampu mengembangkan program pengajaran yang diartikan sebagai suatu proses yang harus dilakukan oleh pendidik dalam membimbing, membantu, dan mengarahkan peserta didik untuk memiliki pengalaman belajar. Karena pengajaran adalah suatu proses maka di dalamnya mengandung suatu perencanaan dalam proses penyusunan materi pengajaran, penggunaan media, penggunaan pendekatan dan metode pengajaran serta suatu penilaian dalam suatu alokasi waktu tertentu dalam mencapai tujuan.

Menurut Abdul Majid (2008 : 18 ) bahwa perencanaan dapat dilihat dari berbagai sudut pandang salah satunya adalah perencanaan pengajaran sebagai sebuah proses adalah pengembangan pengajaran secara sistemik yang digunakan secara khusus atas dasar teoriteori pembelajaran dan pengajaran untuk menjamin kualitas pembelajaran.

Dalam proses pembelajaran yang kami lakukan khususnya pada mata pelajaran IPA (Fisika) pada konsep dasar Kelistrikan pada peserta didik kelas IX B tahun pelajaran 2014/2015 mengalami kesulitan belajar karena menurut kami materi ini memiliki tingkat kesulitan yang tinggi, terbukti dengan hasil rata-rata ulangan harian yang masih rendah yaitu 
64,41, rerata ini masih di bawah KKM yang ditetapkan sebesar 67,00.

Dalam menyampaikan materi khususnya materi pada konsep dan Kelistrikan selama ini belum menggunakan model pembelajaran yang tepat, masih cenderung di dominasi oleh metode ceramah, sehingga sedikit melibatkan siswa dalam proses pembelajarannya.

Maka dalam penelitian ini kami menerapkan model pembelajaran kooperatif type Jigsawdi dalam memeperbaiki dan meningkatkan hasil belajar terutama ulangan harian peserta didik.

Model pembelajaran yang kami pilih ini memiliki keunggulan dan memerlukan sistem pengelolaan dan lingkungan belajar yang berbeda dalam memberikan peran kepada siswa pada ruang fisik dan pada sistem sosial kelas. Belajar secara kooperatif dimana siswa belajar dalam kelompok-kelompok kecil yang memiliki tingkat kemampuan berbeda, dalam menyelesaikan tugas pun peserta didik bekerja sama dan membantu dalam kelompoknya untuk memahami suatu bahan pembelajaran. Dalam pembelajaran kooperatif ini sesuai dengan pilar-pilar CTL yaitu learning community.

Alasan lain pemilihan model pembelajaran kooperatif ini dikembangkan untuk mencapai hasil belajar akademik dalam memahami konsep-konsep yang sulit dan juga efektif untuk mengembangkan ketrampilan sosial siswa. Selain itu dapat memberi keuntungan pada peserta didik kelompok atas menjadi tutor sebaya kelompok bawah dalam bekerja sama menyelesaikan tugas-tugas.

Model pembelajaran ini dapat juga membekali peserta didik suatu ketrampilan bekerjasama dan berkolaborasi, kedua keterampilan ini sangat diperlukan di dalam kehidupan bermasyarakat kelak.

Setelah proses pembelajaran berlangsung diharapakan terjadi peningkatan rerata nilai ulangan harian pada kompetensi dasar Kelistrikan $\geq$ KKM yang telah ditetapkan sebesar 67, sedangkan bagi peneliti selanjutnya dapat memperbaiki proses pembelajaran dengan model - model pembelajaran yang bervariasi.

Maka dalam penelitian ini menerapkan model pembelajaran kooperatif type Jigsaw untuk meningkatkan aktivitas dan hasil belajar terutama ulangan harian peserta didik. Model pembelajaran yang dipilih memiliki keunggulan serta memerlukan sistem pengelolaan dan lingkungan belajar yang berbeda dalam memberikan peran kepada siswa pada ruang fisik dan pada sistem sosial kelas. Belajar secara kooperatif dimana siswa belajar dalam kelompok-kelompok kecil siswa dibagi berkelompok dengan anggota kelompok 5 atau 6 orang heterogen. Materi pelajaran diberikan kepada siswa dalam bentuk teks yang telah dibagi-bagi menjadi beberapa sub-bab. Anggota dari kelompok lain yang telah mempelajari sub-bab yang sama bertemu dengan kelompok-kelompok ahli untuk mendiskusikan sub-bab mereka. Setelah itupara siswa kembali ke kelompok asal mereka dan bergantian mengajar teman satu kelompok mereka tentang sub-bab mereka. Satu-satunya cara siswa dapat belajar sub-bab lain selain dari sub-bab yang mereka pelajari adalah dengan mendengarkan dengan sungguh-sungguh terhadap teman satu kelompok mereka. Setelah selesai pertemuan dan diskusi kelompok asal, siswa-siswa dikenai kuis secara individu tentang materi belajar.

Setelah proses pembelajaran berlangsung diharapkan terjadi peningkatan aktivitas dan rerata nilai ulangan harian $\geq$ KKM yang telah ditetapkan sebesar 67, sedangkan bagi peneliti selanjutnya dapat memperbaiki proses pembelajaran dengan model - model pembelajaran yang bervariasi. 
Tujuan penelitian adalah untuk meningkatkan aktivitas dan hasil belajar Fisika sedangkan manfaat penelitian agar siswa lebih kreatif, mampu bekerja sama didalam proses pembelajaran, guru akan lebih bervariasi dalam proses pembelajaran sehingga lebih kreatif, inovatif dalam proses pembelajaran PAIKEM

\section{METODE}

Penelitian dilaksanakan bulan Juli tahun 2014 dilakukan di SMP Negeri 16 Surakarta Jl. Kol, Sutarto 188, pada kelas IX B sebanyak 30 peserta didik terdiri dari 11 peserta didik lakilaki dan 19 peserta didik perempuan.sumber data dalah berupa aktivitas dan nilai ulangan harian. Analisis data yang berupa data kuantitatif dianalisis dengan menggunakan analisis deskriptif komparatif yaitu membandingkan nilai tes kondisi awal, nilai tes setelah siklus I dan nilai tes setelah siklus II , untuk data kualitaif hasil pengamatan atau observasi dianalisis dengan menggunakan analisis deskriptif kualitatif berdasarkan hasil observasi dan refleksi dari tiap-tiap siklus.Indikator kinerja adanya peningkatan aktivitas dan hasil belajar berupa kenaikan rata-rata nilai ulangan harian $\geq$ KKM yang ditentukan yaitu sebesar 67 . Metode penelitian yang digunakan adalah Penelitian Tindakan Kelas. meliputi tahap perencanaan, pelaksanaan tindakan, pengamatan dan refleksi, tahapan tersebut disusun dalam dua (2) siklus.

\section{HASIL DAN PEMBAHASAN}

Hasil belajar peserta didik pada ulangan harian siklus II jika di bandingkan dengan hasil ulangan harian pada siklus I menghasilkan rata-rata dari 66,17 menjadi 69,17 naik 3 atau (4,53\%), banyaknya peserta didik yang sudah tuntas $\geq$ KKM 67 dari 17 orang (56,67 \%) menjadi 23 orang (77,16 \%) naik sebesar 20,59\%, sedangkan peserta didik yang belum tuntas dari 13 orang (43,33\%) menjadi 7 orang (22,84\% ) turun 18,59\%.Dari perolehan hasil belajar pada siklus II ada kenaikan rerata sebesar 2,82 atau (4,2\%) dan kenaikan peserta didik yang tuntas belajar dengan KKM 67 sebesar 20,59\% serta penurunan peserta didik yang belum tuntas sebesar 20,49 \%. Hal ini dapat sebagai dasar untuk menyimpulkan bahwa proses pembelajaran yang dilakukan dengan model Jigsaw dapat berpengaruh pada perubahan perolehan hasil belajar kearah lebih baik meskipun prosentasenya masih kecil. 


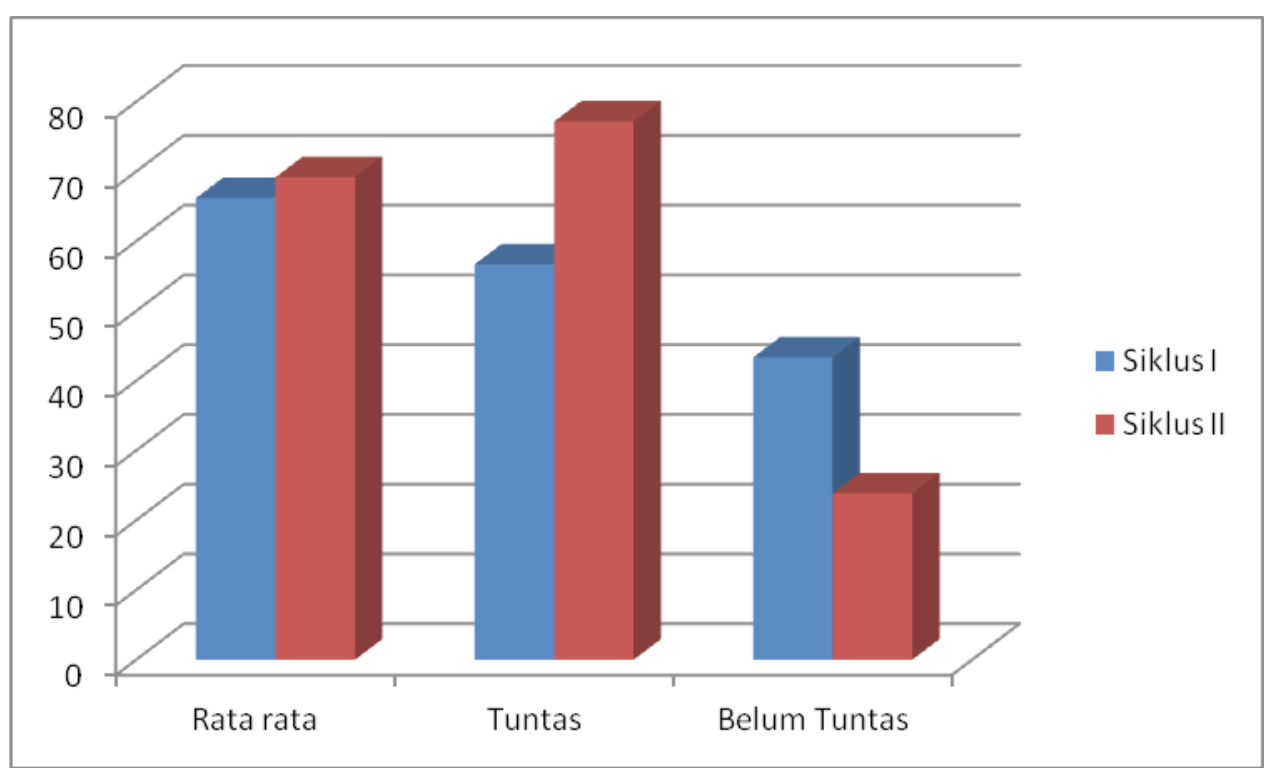

Gambar 1. Hasil belajar peserta didik pada siklus I dan II

Aktivitas peserta didik dalam kegiatan proses pembelajaranpun juga mengalami perubahan jika dibandingkan siklus I dengan siklus II dari hasil pengamatan peneliti dan rekan sejawat, pada aspek A yaitu memperhati kan penjelasan guru rata-rata sebesar 76\% menjadi $90,75 \%$, pada aspek B yaitu keterlibatan dalam diskusi sebesar 66\% menjadi 75,37\% , aspek C yaitu antusiasme dalam pembelajaran diperoleh rata-rata sebesar $66 \%$ menjadi $68,25 \%$, aspek D yaitu keaktifan bertanya dalam kelompok memiliki rerata 47,5\% menjadi 67,25\%, aspek E yaitu menanggapi, bertanya dan menyangkal sebesar 45,5\% menjadi 66,00\%, aspek F yaitu kemampuan presentasi sebesar 29,5\% menjadi 66\%.

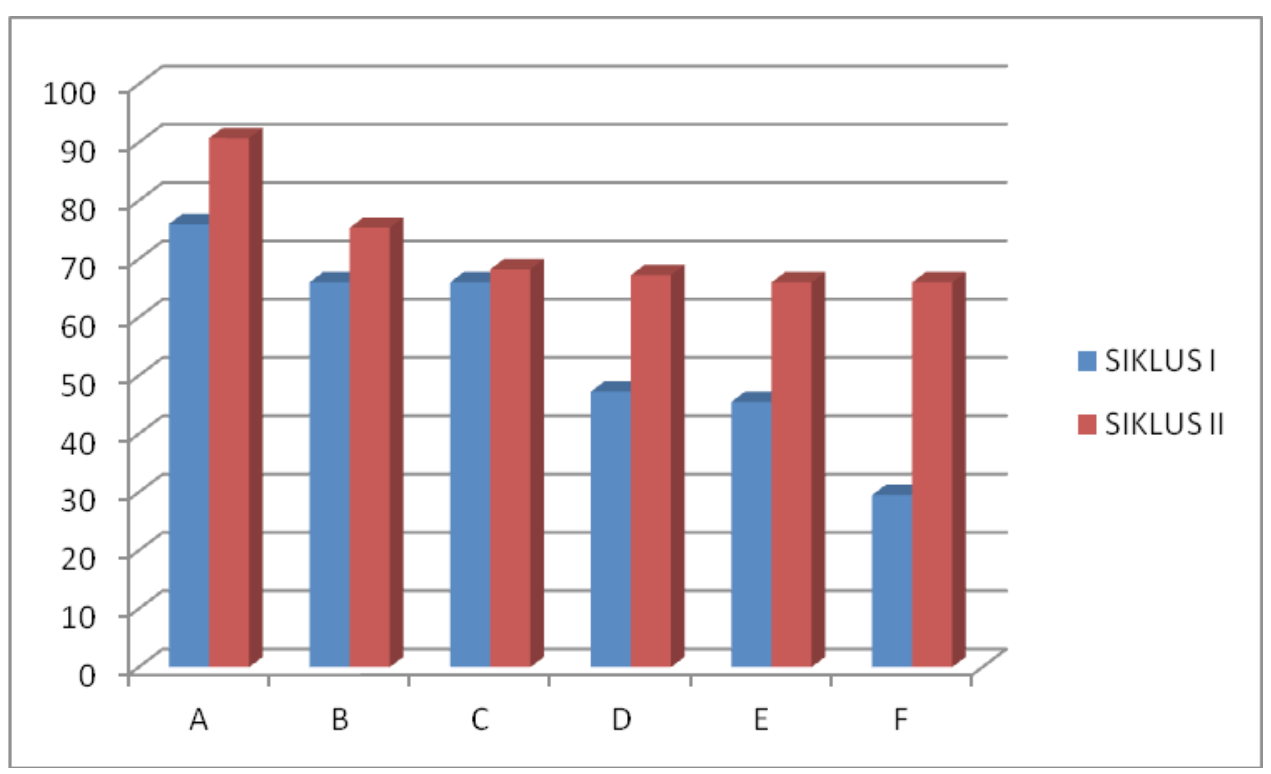

Gambar 2. Aktivitas peserta didik dalam kegiatan proses pembelajaran siklus I dan II

Secara umum maka rerata yang diperoleh dari aspek A sampai F pada siklus I sebesar 45\% menjadi 72,27\% terdapat kenaikan sebesar 27,27\%. Rerata yang diperoleh pada siklus I sebesar 45\% termasuk kategori kurang sedangkan rerata pada siklus II baik. Sehingga dapat 
disimpulkan bahwa kegiatan proses pembelajaran dengan model Jigsaw dapat mempengaruhi aktivitas peserta didik dalam belajar.

Hasil angket tanggapan terhadap proses pembelajaran pada siklus I sebanyak (82,3\%) merasa senang menjadi $94.1 \%$ sedangkan sangat senang sebesar 5,8\%, ragu-ragu dari $17.6 \%$ menjadi $0 \%$. Tanggapan peserta didik mengenai kejelasan dalam menerima materi sebesar $64,7 \%$ menjadi $91,1 \%$, dan yang masih merasa dari sebesar $11,7 \%$ menjadi $0 \%$ sedangkan ragu-ragu 23,5\% menjadi $8,82 \%$. Tanggapan peserta didik terhadap pembelajaran dengan model kooperatif yaitu merasa senang dari sebesar 79,4\% menjadi 91,1\%,sedang 20,5\%nya masih merasa ragu-ragu menjadi 5,8\%. Selanjutnya tanggapan mengenai pembagian kelompok semua peserta didik sudah merasa cocok (100\%) baik pada siklus I maupun siklus II. Tanggapan mengenai penyajian hasil diskusi yang dilakukan oleh kelompok $(73,5 \%)$ merasa senang menjadi 88,2\% serta ragu-ragu terhadap penyajian kelompok lain 20,5\% menjadi $11,7 \%$.

Hasil refleksi tersebut maka dapat disimpulkan bahwa hasil belajar peserta didik dapat ditingkatkan baik rerata, ketuntasan hasil belajar, sedangkan untuk aktivitas peseta didik dalam mengikuti proses pembelajaran diperoleh rata-rata sebesar 45\% menjadi 72,27\% terdapat kenaikan sebesar 27,27\%. dari rata-rata tersebut termasuk kategori baik.

Hal ini terbukti hasil belajar pada saat kondisi awal, siklus I dan siklus II mengalami peningkatan baik rerata dan ketuntasannya. Rata-rata hasil ulangan harian pada kondisi awal sebesar 62,67 setelah siklus I menjadi 66,17 sedangkan rata - rata hasil tes setelah siklus II sebesar 69,17, apabila rata-rata pada siklus II dibandingkan dengan kondisi awal dan siklus I mengalami kenaikan 6,5 (10,37 \% ) dan 3 ( 4,53 \%).

Selanjutnya apabila di lihat dari ketercapaian ketuntasan baik pada saat kondisi awal , setelah siklus I dan siklus II maka banyaknya peserta didik yang sudah tuntas $\geq$ KKM 67 pada saat kondisi awal adalah sebanyak 6 orang (20\%), 17 orang (56,67\%) pada siklus I, sedangkan pada siklus II sebanyak 23 peserta didik atau 77,16 \%. Sedangkan peserta didik yang belum tuntas dari kondisi awal, setelah siklus I dan siklus II sebanyak 24 orang (80 \%), 13 orang (43,33 \%) menjadi 7 orang atau $22,84 \%$.

Aktivitas peserta didik selama proses pembelajaran pada siklus I dan II juga terjadi peningkatan Secara umum rerata yang diperoleh dari aspek A sampai F pada siklus I sebesar 45\% menjadi 72,27\% terdapat kenaikan sebesar 27,27\%. Rerata yang diperoleh pada siklus I sebesar $45 \%$ termasuk kategori kurang sedangkan rerata pada siklus II baik. Sehingga kegiatan proses pembelajaran dengan model NHT dapat mempengaruhi aktivitas peserta didik dalam belajar.

Hasil pembahasan sebelumnya nyata terdapat kenaikan hasil belajar dari kondisi awal, siklus I dan siklus II rerata dan ketuntasannya. Rata-rata hasil ulangan harian pada kondisi awal sebesar 62,67 menjadi 66,17 sedang kan rata - rata hasil tes setelah siklus II sebesar $69,17$.

Selanjutnya dari ketercapaian ketuntasan baik pada saat kondisi awal , setelah siklus I dan siklus II maka banyaknya peserta didik yang sudah tuntas $\geq$ KKM 67 pada saat kondisi awal adalah sebanyak 6 orang (20\%), 17 orang (56,67n \%) sedangkan pada siklus II sebanyak 23 peserta didik atau $77,16 \%$. 
Peserta didik yang belum tuntas dari kondisi awal, setelah siklus I dan siklus II sebanyak 24 orang (80\%), 13 orang (43,33 \%) menjadi 7 orang atau 22,84 \%. Dengan demikian maka melalui penerapan model pembelajaran kooperatif Jigsawdapat meningkatan hasil belajar.

Aktivitas peserta didik selama proses pembelajaran dapat ditingkatkan melalui model pembelajaran Jigsaw. Hal ini terbukti dengan meningkatnya rerata aktivitas yang diperoleh dari aspek A sampai F sebesar 45\% menjadi 72,27\%.

\section{SIMPULAN}

Hasil belajar peserta didik kelas IX B SMP Negeri 16 Surakarta, semester I tahun 2014/2015 pada konsep dasar Kelistrikan melalui penerapan model pembelajaran kooperatif Jigsaw dapat meningkat meliputi rerata dari 62,67 menjadi 66,17 sedangkan rata - rata hasil tes setelah siklus II sebesar 69,17. Ketuntasan dari 6 orang (20\%), menjadi 17 orang (56,67 \%) kemudian 23 orang atau 77,16\%.

Aktivitas peserta didik selama proses pembelajaran dapat ditingkatkan melalui model pembelajaran Jigsaw. Hal ini terbukti dengan meningkatnya rerata aktivitas yang diperoleh dari aspek A sampai F sebesar 45\% menjadi 72,27\%.

\section{DAFTAR PUSTAKA}

Arini, Yusti, 2009, Model Pembelajaran Kooperatif, http://yusti arini.blogspot.com/2009/08/ model-pembelajaran-kooperatif.html

Hamalik, O,2001, Proses Belajar Mengajar, Jakarta: Bumi Aksara

Herdian, 2009, Model Pembelajaran Kooperatif, http:// herdy07 .wordpress.com/2009/04/22/ model -pembelajaran-nht-numberd-head together/

Majid, Abdul, 2008, Perencanaan Pembelajaran, Bandung: Remaja Rosda Karya

Saktiyono, 2002, IPA Fisika 3, Jakarta: Esis

Soejanto,Agoes,1997, Bimbingan Ke Arah Belajar Yang Sukses, Surabaya: Rineka Cipta.

Sudjana, Nana, 2001, Penilaian Hasil Proses Belajar Mengajar, Bandung : Remaja Rosdakaya.

Sunarwan, dkk, 2000, IPA Fisika Untuk Kelas 3 SMP, Jakarta: Erlangga

Usman,Uzer,1995, Menjadi Guru Profesional, Bandung, Remaja Rosdakarya

Wartono,dkk, 2004, Materi Pelatihan Terintegrasi Sains, Jakarta: DirPend Lanjutan Pertama, Dijendikdasmen Depdiknas. 